\title{
Rapid depletion of B lymphocytes by ultra-low-dose rituximab delivered intrathecally
}

\section{OPEN}

Anders Svenningsson, MD

Joakim Bergman, MSc Ann Dring, PhD Mattias Vågberg, MD Richard Birgander, MD Thomas Lindquist, MD Jonathan Gilthorpe, PhD Tommy Bergenheim, MD

Correspondence to Dr. Svenningsson: anders.svenningsson@ neuro.umu.se

\section{ABSTRACT}

Objective: We are conducting an open-label phase $1 \mathrm{~b}$ study on the efficacy of intrathecal (IT) administration of rituximab, provided via an Ommaya reservoir, for the treatment of progressive multiple sclerosis (PMS). The objective of this initial study was to monitor B lymphocytes in peripheral blood (PB) and CSF from the first 10 patients 1 year posttreatment.

Methods: Dose titration was performed with daily escalation from $1 \mathrm{mg}$ to $25 \mathrm{mg}$ IT rituximab $(n=3)$. Lymphocyte subpopulations were monitored daily during dose escalation in PB by flow cytometry and subsequently every 3 months for 1 year, after a total dose of $3 \times 25 \mathrm{mg}$. PB B-lymphocyte subpopulations for the remaining patients $(n=7)$ were monitored at regular intervals. CSF lymphocyte subpopulations for all patients were monitored by flow cytometry every 2-3 months.

Results: The PB B-lymphocyte count dropped rapidly after the first 2 injections (total dose of 3.5 mg IT rituximab) to undetectable levels. Three 25-mg doses given once per week depleted peripheral B lymphocytes entirely for the following 3-6 month period.

Conclusions: Monoclonal antibodies seem to rapidly redistribute to the peripheral compartment following IT injection. Ultra-low doses of rituximab given IT are sufficient to cause complete depletion of peripheral B lymphocytes, indicating that low-dose IT treatment has the potential to be effective in both the CNS and systemic compartments.

Classification of evidence: This study provides Class IV evidence that for patients with PMS, rituximab provided via an Ommaya reservoir depletes peripheral blood B lymphocytes. Neurol Neuroimmunol Neuroinflamm 2015;2:e79; doi: 10.1212/NXI.0000000000000079

\section{GLOSSARY}

BBB = blood-brain barrier; EAE = experimental autoimmune encephalomyelitis; IT = intrathecal; $\mathbf{M S}=$ multiple sclerosis; $\mathbf{P B}=$ peripheral blood; $\mathbf{P M S}=$ progressive MS.

Multiple sclerosis (MS) is an immune-mediated disorder of the CNS. Immunomodulatory drugs administered systemically can efficiently treat relapsing-remitting $\mathrm{MS}^{1-3}$ but have little or no effect on progressive MS (PMS). ${ }^{4}$

Evidence exists for the presence of a chronic low-grade inflammatory process within the CNS that correlates with the progressive phase of disease. ${ }^{4-6}$ Therapeutic antibodies cross the intact blood-brain barrier (BBB) with low efficiency, achieving CSF concentrations of only $0.1 \%-0.5 \%$ of the corresponding level in plasma, ${ }^{7,8}$ which may partially explain treatment failure in PMS.

Intrathecal (IT) administration of the monoclonal antibody rituximab (Mabthera, Rituxan) is used to treat CNS manifestations of B-cell lymphoma with relatively few side effects and low risk. ${ }^{8,9}$

We have initiated a phase $1 \mathrm{~b}$ study to investigate the safety, feasibility, and efficacy of rituximab administered IT as a potential therapy in a group of patients with PMS. In this substudy, we describe early observations regarding the pattern of B-lymphocyte depletion following IT injection of ultra-low doses of rituximab.

From the Department of Pharmacology and Clinical Neuroscience (A.S., J.B., A.D., M.V., J.G., T.B.) and Department of Radiation Sciences (R.B., T.L.), Diagnostic Radiology, Umeå University, Sweden.

Go to Neurology.org/nn for full disclosures. Funding information and disclosures deemed relevant by the authors, if any, are provided at the end of the article. The Article Processing Charge was paid by the authors.

This is an open access article distributed under the terms of the Creative Commons Attribution-Noncommercial No Derivative 3.0 License, which permits downloading and sharing the work provided it is properly cited. The work cannot be changed in any way or used commercially. 
METHODS Standard protocol approvals, registrations, and patient consents. The ITT-PMS trial (ClinicalTrials.gov identifier NCT01719159) is an open-label interventional study primarily aimed at studying the feasibility and safety of IT administration of rituximab in PMS. A secondary endpoint is to study treatment effects on subsets of lymphocytes in peripheral blood (PB) and CSF. Inclusion criteria were a diagnosis of PMS and a failure to respond to or ineligibility for conventional therapies. Ten patients were included from September 2009 to March 2011 and followed for 1 year. Informed consent was obtained prior to enrollment, and the study was approved by the Regional Ethical Review Board of Umeå University (Dnr 08-157M).

The primary research question of this substudy was whether injection of rituximab would cause depletion of PB B lymphocytes. This observational study without a control group provides Class IV evidence regarding this question.

Surgery. Under general anesthesia, a ventricular catheter was introduced into the right frontal horn through a $10 \mathrm{~mm}$ diameter

\section{Figure 1 Peripheral blood lymphocyte counts during dose titration}

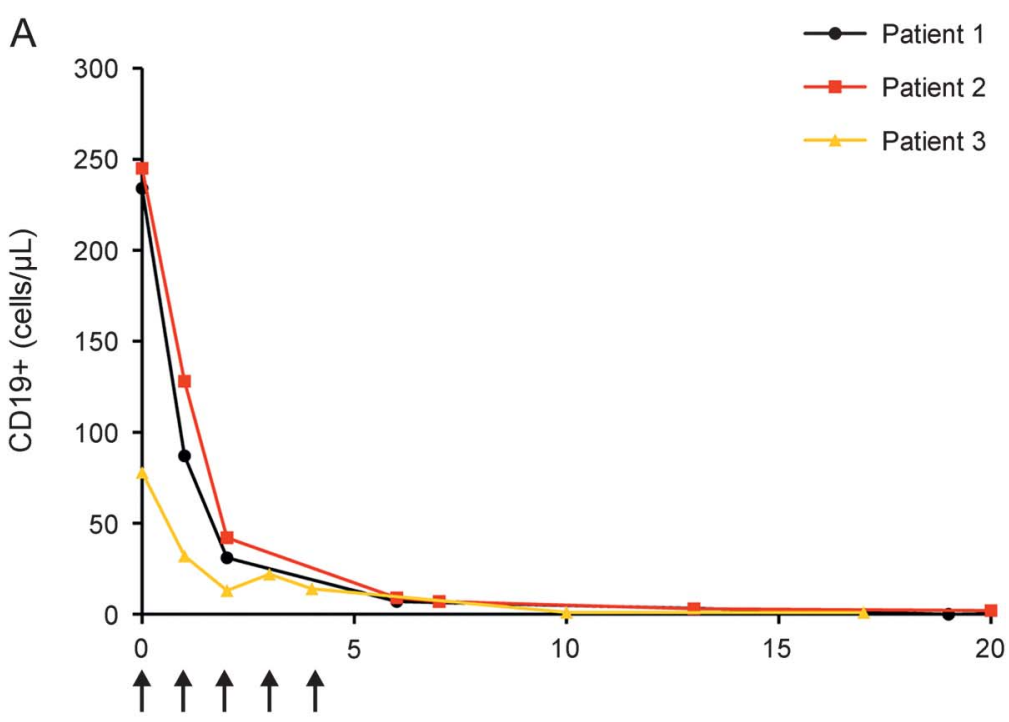

B

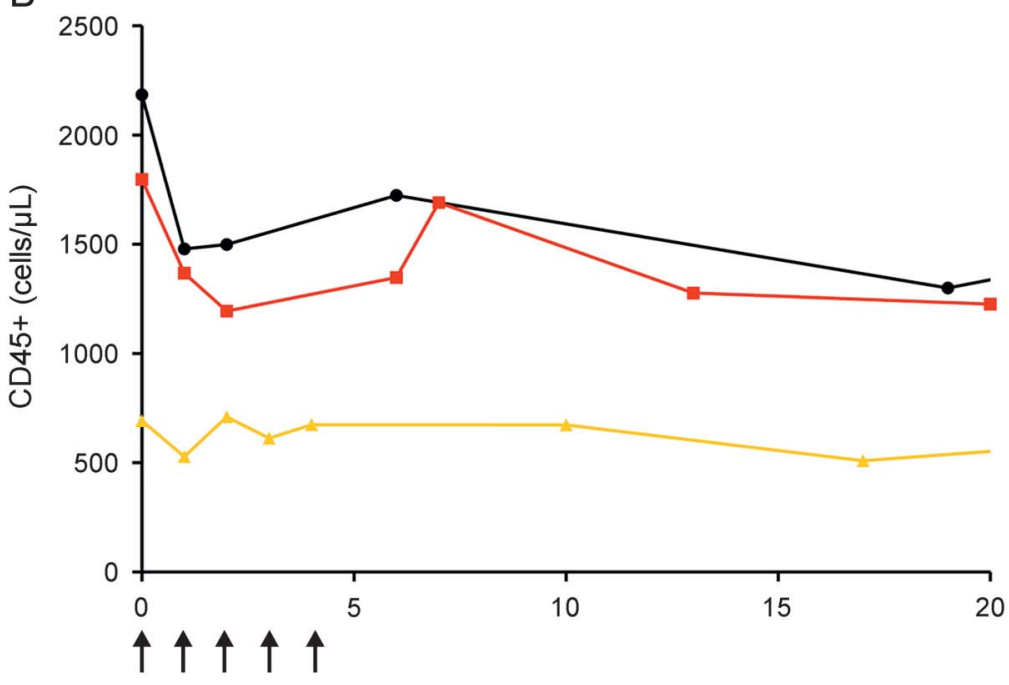

Days post-treatment

B-lymphocyte $\left(\mathrm{CD} 19^{+} ; \mathrm{A}\right)$ and total lymphocyte $\left(\mathrm{CD} 45^{+} ; \mathrm{B}\right)$ counts (cells $\left./ \mu \mathrm{L}\right)$ in peripheral blood during dose titration $(n=3)$. Treatment days indicated by vertical arrows. burr hole placed $2 \mathrm{~cm}$ to the right of the midline at the level of the coronal suture and connected to a subcutaneous Ommaya reservoir.

Treatment. Rituximab (10 mg/mL; Roche AB, Stockholm, Sweden) was administered as 3 doses of $25 \mathrm{mg}$ at weekly intervals. The first injection was performed approximately 3 weeks after implantation of the Ommaya reservoir in order to allow surgery-related subcutaneous swelling to subside. Patients were premedicated with $1 \mathrm{mg}$ IV clemastine and $4 \mathrm{mg}$ oral betamethasone 1 hour before the IT rituximab injection. In order to assess tolerance, the rituximab dose was titrated for the first 3 patients, with daily doses of $1 \mathrm{mg}, 2.5 \mathrm{mg}, 5 \mathrm{mg}, 10 \mathrm{mg}$, and finally $25 \mathrm{mg}$. Daily monitoring of routine blood parameters and lymphocyte subpopulations by flow cytometry was performed to assess the safety and pharmacodynamic profile of IT treatment.

Clinical evaluations. Patients were evaluated clinically at baseline and then at 1, 3, 6, 9, and 12 months posttreatment. Lumbar puncture was performed at each visit to follow IM parameters and axonal damage markers.

Flow cytometry. Flow cytometry was performed on PB and CSF cells. Lymphocyte subsets were determined using monoclonal antibodies to the following surface antigens: $\mathrm{CD} 3$ (BD 560365), CD4 (BD 341115), CD8 (BD 345772), CD16 ${ }^{+}$ CD56 (BD 337166), CD45 (BD 560777; BD Biosciences, San Jose, CA), and CD19 (302230; Biosite, San Diego, CA). CSF was centrifuged at $800 \mathrm{~g}$ for 15 minutes, supernatant was gently removed, and the cell pellet was resuspended in phosphatebuffered saline before analysis using a FACSCanto II (BD Biosciences).

RESULTS Daily flow cytometry during dose titration revealed a remarkable effect on peripheral B lymphocytes. One day after the first dose $(1 \mathrm{mg})$, peripheral B lymphocytes were clearly depleted, and after the second day's dose $(2.5 \mathrm{mg})$, peripheral B lymphocytes were virtually undetectable (figure $1 \mathrm{~A}$ ). The total peripheral CD $45^{+}$lymphocyte counts were also immediately lowered (figure 1B).

The full dose $(3 \times 25 \mathrm{mg}$ given 1 week apart $)$ resulted in complete depletion of peripheral B lymphocytes for 3-6 months and an initial reduction of total CD $45^{+}$lymphocytes (figure 2). Most patients had very low CSF lymphocyte counts prior to treatment, which reduced them even further, making consistent changes difficult to evaluate. In 2 patients in whom the initial cell counts were slightly elevated, the same pattern of depletion was seen in the CSF as in PB: an immediate drop in both B lymphocytes and total CD $45^{+}$lymphocytes (figure 3 ).

The primary outcome of the clinical trial, safety and tolerability, will be presented when the trial is complete. Up to this point, no unexpected side effects have occurred; the most common side effect is transient vertigo in conjunction with the IT injections. The only serious side effect so far has been a low virulent infection introduced via the Ommaya reservoir that responded promptly to standard antibiotic treatment and removal of the reservoir. 
Figure 2 Posttreatment peripheral blood lymphocyte counts

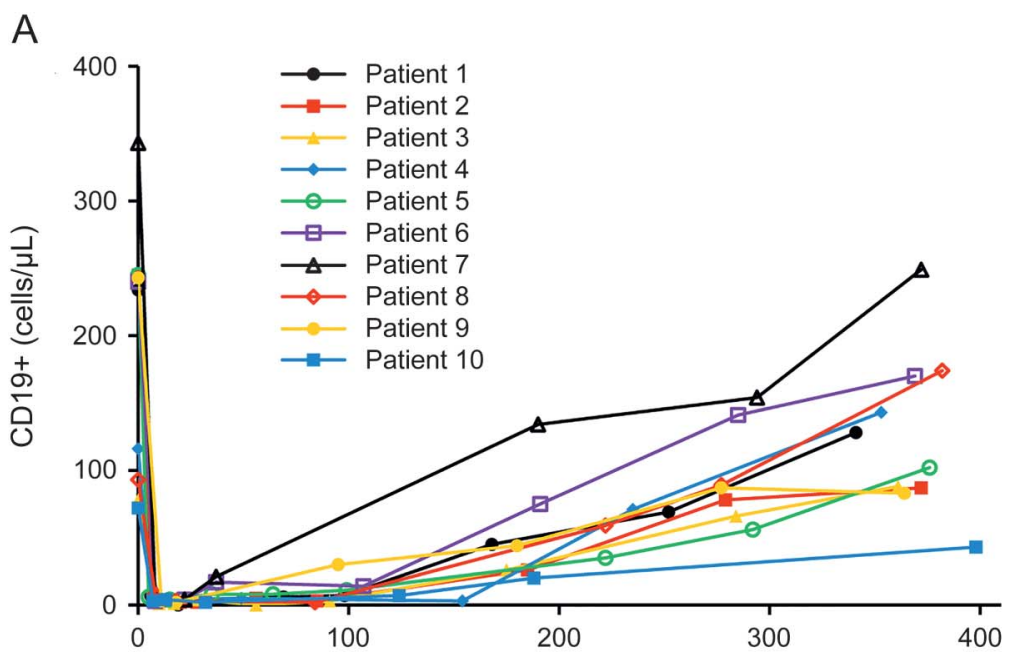

B

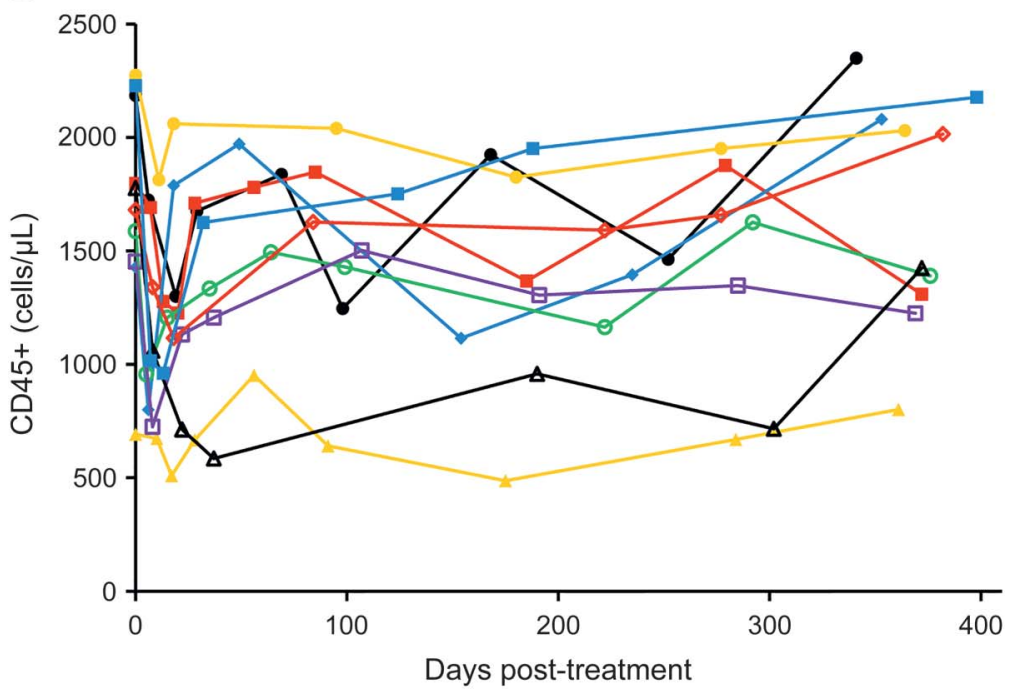

B-lymphocyte $\left(\mathrm{CD} 19^{+} ; \mathrm{A}\right)$ and total lymphocyte $\left(\mathrm{CD} 45^{+} ; \mathrm{B}\right)$ counts (cells $\left./ \mu \mathrm{L}\right)$ in peripheral blood for 1 year posttreatment $(n=10)$.

DISCUSSION In this ongoing trial, we observed an almost immediate effect on B-lymphocyte counts in the peripheral compartment at ultra-low doses of intrathecally administered rituximab. Following a dose of $3.5 \mathrm{mg}$ given over 2 days, peripheral $\mathrm{B}$ lymphocytes were essentially eliminated, and the total dose of $3 \times 25 \mathrm{mg}$ given 1 week apart resulted in complete peripheral depletion of $B$ lymphocytes for 3-6 months. There was a concomitant depletion of total CSF lymphocytes and B lymphocytes, albeit with low baseline counts. Although the rationale for administering rituximab IT was to achieve an effective therapeutic antibody concentration within the $\mathrm{BBB}$, we observed a rapid and potent effect on lymphocytes in the peripheral compartment.

It has previously been shown in nonhuman primates that the pharmacokinetics of rituximab delivered
IT involves a biphasic clearance with a 5-hour terminal half-life of the drug in the CSF compartment, ${ }^{10}$ which concurs with the observations in the present study. Similar depletion of peripheral B lymphocytes was also noted in a recent study of IT administration of anti-CD20 antibodies in experimental autoimmune encephalomyelitis (EAE). ${ }^{11}$ Hence, it is important to evaluate the effect on CSF lymphocytes, considering the rapid clearance from the IT compartment. Only 2 patients had a high enough baseline CSF total cell count to be able to reliably discern a change posttreatment. Both showed an initial depletion of B lymphocytes with a return to baseline by 6 months. Total CSF lymphocyte counts also decreased to almost zero in these 2 patients, which cannot be explained by B-lymphocyte depletion alone. This is in agreement with previous data on CSF $\mathrm{T}$ cells after rituximab treatment, but the exact mechanisms are unknown. ${ }^{12}$ The recently described effect of rituximab on a subset of $\mathrm{T}$ cells expressing CD20 is an interesting mechanism that needs to be investigated further. ${ }^{13}$

A weakness in our study is that we cannot determine whether changes occurring among lymphocyte subsets in the CSF are an effect of rituximab within the CNS compartment or are a result of a peripheral depletion and subsequently less recruitment into the CSF from PB. It is presently not known whether appropriate effector mechanisms exist in the CSF to mediate lysis by injected monoclonal antibodies. However, there is now believed to be an inflammatory milieu along the meninges in many cases of PMS $^{14}$ that could possibly facilitate both complement-mediated lysis and antibody-dependent cytotoxicity. There are also data indicating increased complement activation in MS, with the highest occurrence among progressive patients. ${ }^{15}$ Furthermore, it was shown that IT administration of antiCD20 monoclonal antibody could reduce the amount of B lymphocytes in the meninges in EAE with a concomitant modest amelioration of the clinical course. ${ }^{11}$ There is a need for further research in this area in order to define the role of IT therapy in neuroinflammatory conditions.

We report an unexpected and profound effect on peripheral B lymphocytes after even minute doses of rituximab injected IT. Furthermore, the total dose of $75 \mathrm{mg}$ rituximab given in the CSF compartment resulted in complete depletion of peripheral B lymphocytes for up to 6 months. This indicates that present doses of 500-1,000 mg given intravenously in the clinic may be unnecessarily high. The data also indicate a possible effect on CSF lymphocytes, which requires further study. The rapid redistribution of IT-injected rituximab to the peripheral compartment has strong implications regarding the 


\section{Figure 3 Posttreatment CSF lymphocyte counts}

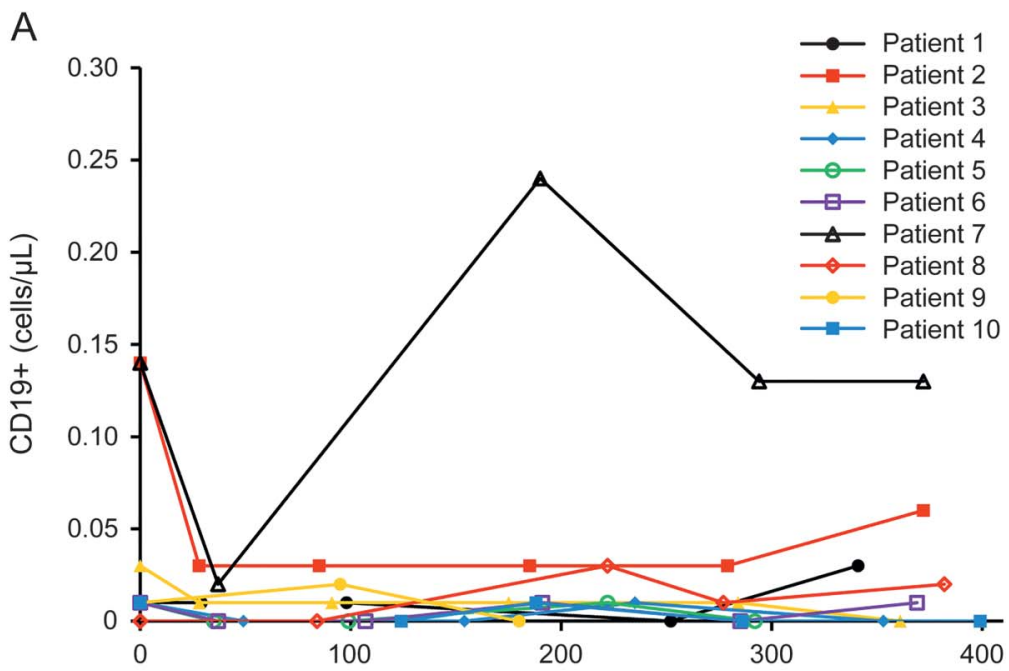

B

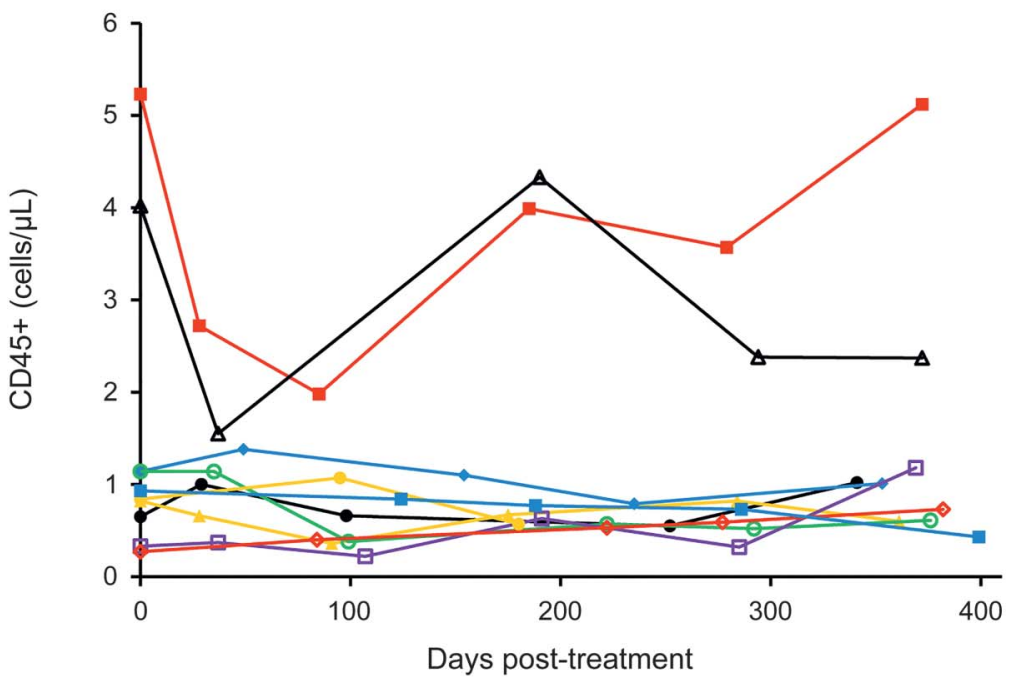

B-lymphocyte $\left(\mathrm{CD} 19^{+} ; \mathrm{A}\right)$ and total lymphocyte $\left(\mathrm{CD} 45^{+} ; \mathrm{B}\right)$ counts (cells $\left./ \mu \mathrm{L}\right)$ in $\mathrm{CSF}$ for 1 year posttreatment $(n=10)$.
University and Västerbotten County Council on cooperation in the field of Medicine, Odontology and Health (ALF).

\section{DISCLOSURE}

A. Svenningsson has served on the advisory boards for Sanofi-Genzyme and Biogen Idec; has received travel funding and/or speaker honoraria from Biogen Idec, Sanofi-Genzyme, Novartis, and Baxter Medical; and has received research support from Biogen Idec. J. Bergman and A. Dring report no disclosures. M. Vågberg has received travel funding and/or speaker honoraria from Biogen Idec, Novartis, Baxter Medical, and Pharma Industry writing honoraria and has received research support from Biogen Idec and Neuro Sweden. R. Birgander, T. Lindqvist, and J. Gilthorpe report no disclosures. T. Bergenheim has received research support from Swedish Cancer Society. Go to Neurology.org/nn for full disclosures.

Received October 8, 2014. Accepted in final form January 13, 2015.

\section{REFERENCES}

1. Buttmann M, Rieckmann P. Interferon-beta1b in multiple sclerosis. Exp Rev Neurother 2007;7:227-239.

2. Polman $\mathrm{CH}$, O'Connor PW, Havrdova E, et al. A randomized, placebo-controlled trial of natalizumab for relapsing multiple sclerosis. N Engl J Med 2006;354: 899-910.

3. Jones JL, Coles AJ. Campath-1H treatment of multiple sclerosis. Neurodegener Dis 2008;5:27-31.

4. Lassmann H. New concepts on progressive multiple sclerosis. Curr Neurol Neurosci Rep 2007;7:239-244.

5. Serafini B, Rosicarelli B, Franciotta D, et al. Dysregulated Epstein-Barr virus infection in the multiple sclerosis brain. J Exp Med 2007;204:2899-2912.

6. Lassmann H. Multiple sclerosis: is there neurodegeneration independent from inflammation? J Neurol Sci 2007; 259:3-6.

7. Banks WA, Terrell B, Farr SA, Robinson SM, Nonaka N, Morley JE. Passage of amyloid beta protein antibody across the blood-brain barrier in a mouse model of Alzheimer's disease. Peptides 2002;23:2223-2226.

8. Rubenstein JL, Fridlyand J, Abrey L, et al. Phase I study of intraventricular administration of rituximab in patients with recurrent CNS and intraocular lymphoma. J Clin Oncol 2007;25:1350-1356.

9. Perissinotti AJ, Reeves DJ. Role of intrathecal rituximab and trastuzumab in the management of leptomeningeal carcinomatosis. Ann Pharmacother 2010;44:1633-1640.

10. Rubenstein JL, Combs D, Rosenberg J, et al. Rituximab therapy for CNS lymphomas: targeting the leptomeningeal compartment. Blood 2003;101:466-468.

11. Lehmann-Horn K, Kinzel S, Feldmann L, et al. Intrathecal anti-CD20 efficiently depletes meningeal B cells in CNS autoimmunity. Ann Clin Transl Neurol 2014;1:490-496.

12. Cross AH, Stark JL, Lauber J, Ramsbottom MJ, Lyons JA. Rituximab reduces $\mathrm{B}$ cells and $\mathrm{T}$ cells in cerebrospinal fluid of multiple sclerosis patients. J Neuroimmunol 2006;180: 63-70.

13. Palanichamy A, Jahn S, Nickles D, et al. Rituximab efficiently depletes increased CD20-expressing T cells in multiple sclerosis patients. J Immunol 2014;193:580-586.

14. Choi SR, Howell OW, Carassiti D, et al. Meningeal inflammation plays a role in the pathology of primary progressive multiple sclerosis. Brain 2012;135:2925-2937.

15. Trbojevic-Cepe M, Brinar V, Pauro M, Vogrinc Z, Stambuk N. Cerebrospinal fluid complement activation in neurological diseases. J Neurol Sci 1998;154:173-181.

\section{STUDY FUNDING}

The study was funded by the Research Fund for Clinical Neuroscience at Umeå University Hospital and the Regional agreement between Umeå 


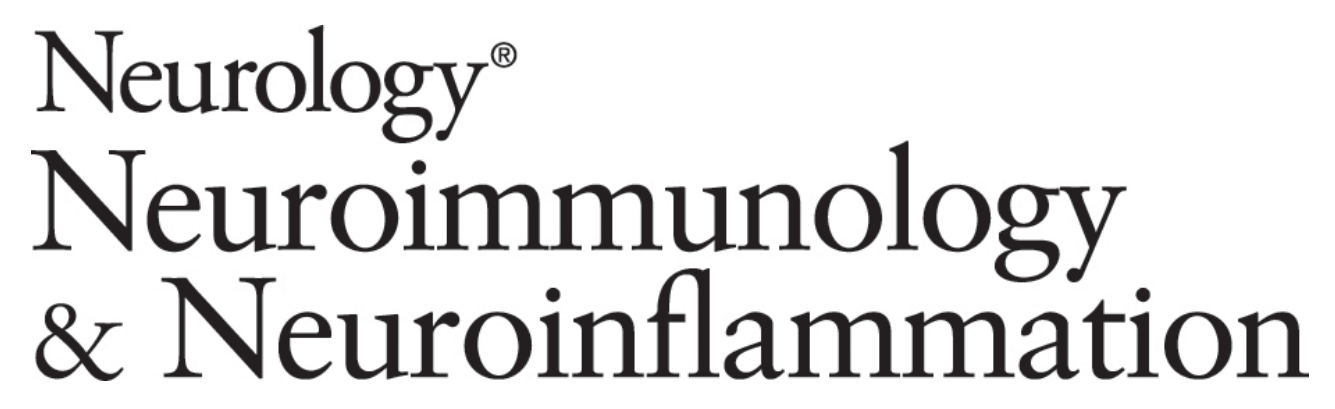
Rapid depletion of B lymphocytes by ultra-low-dose rituximab delivered intrathecally Anders Svenningsson, Joakim Bergman, Ann Dring, et al.
Neurol Neuroimmunol Neuroinflamm 2015;2;
DOI 10.1212/NXI.0000000000000079

This information is current as of February 26, 2015

Neurol Neuroimmunol Neuroinflamm is an official journal of the American Academy of Neurology.

Published since April 2014, it is an open-access, online-only, continuous publication journal. Copyright $\odot$ 2015 American Academy of Neurology. All rights reserved. Online ISSN: 2332-7812.

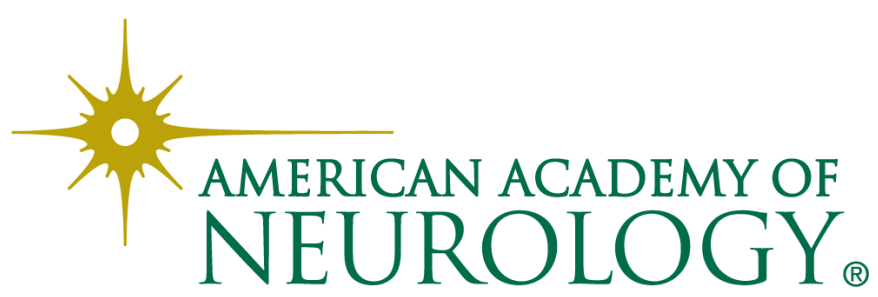




\section{Updated Information \& Services}

References

Citations

Subspecialty Collections

Permissions \& Licensing

Reprints including high resolution figures, can be found at: http://nn.neurology.org/content/2/2/e79.full.html

This article cites 15 articles, 4 of which you can access for free at: http://nn.neurology.org/content/2/2/e79.full.html\#\#ref-list-1

This article has been cited by 2 HighWire-hosted articles: http://nn.neurology.org/content/2/2/e79.full.html\#\#otherarticles

This article, along with others on similar topics, appears in the following collection(s):

Autoimmune diseases

http://nn.neurology.org//cgi/collection/autoimmune_diseases Class IV

http://nn.neurology.org//cgi/collection/class_iv

Clinical trials Observational study (Cohort, Case control)

http://nn.neurology.org//cgi/collection/clinical_trials_observational_stu dy_cohort_case_control

Multiple sclerosis

http://nn.neurology.org//cgi/collection/multiple_sclerosis

Information about reproducing this article in parts (figures,tables) or in its entirety can be found online at:

http://nn.neurology.org/misc/about.xhtml\#permissions

Information about ordering reprints can be found online: http://nn.neurology.org/misc/addir.xhtml\#reprintsus

Neurol Neuroimmunol Neuroinflamm is an official journal of the American Academy of Neurology.

Published since April 2014, it is an open-access, online-only, continuous publication journal. Copyright $\odot$ 2015 American Academy of Neurology. All rights reserved. Online ISSN: 2332-7812.

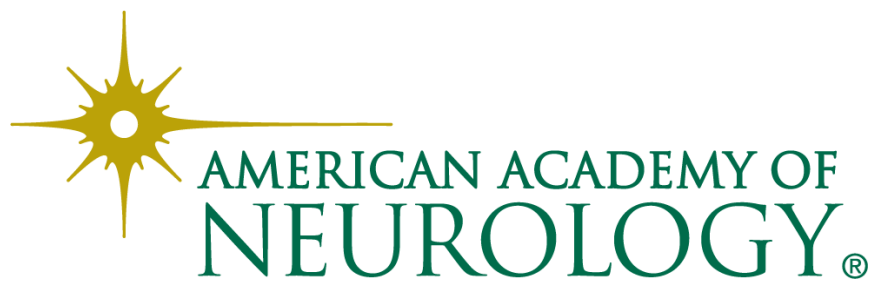

